\title{
Retracted: Eliciting broadly neutralizing antibodies against HIV-1 that target gp41 MPER
}

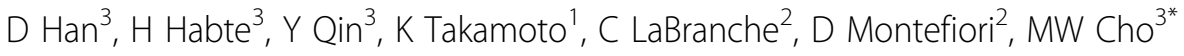 \\ From AIDS Vaccine 2012 \\ Boston, MA, USA. 9-12 September 2012 \\ A notice has been published about this article. See full information at: Retrovirology 2014, 11:16
}

\section{Background}

The membrane-proximal external region (MPER) of HIV-1 gp41 is highly conserved and is targeted by broadly neutralizing antibodies (bnAbs). Thus, it is an attractive target for AIDS vaccine development. Here, we describe a mini-protein that can induce bnAbs in rabbits.

\section{Methods}

We generated a mini-protein that is structurally rigid, yet efficiently recognized by $2 \mathrm{~F} 5,4 \mathrm{E} 10$ and Z13e1. It contains the C-terminal 54 a.a. of gp41 ectodomain (gp41-54Q), which includes the HR2 and the MPER. A 6xHis tag at the C-terminus was used to attach gp41-54Q to Zn-chitosan, which served as an antigen carrier/adjuvant. Rabbits were immunized subcutaneously, 4 times, using two different schedules (wks $0,4,9$ and 16 vs. $0,8,16$ and 24). A total of 9 animals were immunized with gp41-54Q in 3 independent experiments. Antibody responses were evaluated by ELISA and in neutralization assays using both TZM-bl and A3R5.7 cells.

\section{Results}

Eight of nine rabbits mounted bnAbs (89\%). Neutralizing activity was observed against all but two of 44 viruses evaluated to date, including 27 Tier 2 viruses from clades A, B, C, D, AE, and CRF02_AG. Although Nabs could be detected after three immunizations, a fourth immunization was necessary for maximum neutralizing activity. The slower immunization regimen induced higher Nab titers, suggesting that longer rest periods improve affinity maturation. Neutralization inhibition analyses using various peptides identified one neutralizing epitope (N671, W672, F673 and D674) that overlaps with those recognized by Z13e1, 4E10 and 10E8 mAbs. Based on antibody absorption assays, there might be other non-linear

${ }^{3}$ lowa State University, Ames, USA

Full list of author information is available at the end of the article epitopes. We are in the process of generating rabbit mAbs for more detailed analyses.

\section{Conclusion}

We have successfully demonstrated that we can reproducibly induce bnAbs in rabbits using a mini-protein containing gp41 MPER. These results suggest that gp41 can be a promising vaccine immunogen.

\section{Author details}

${ }^{1}$ Albert Einstein College of Medicine, USA. ${ }^{2}$ Duke University, USA. ${ }^{3}$ lowa State University, Ames, USA.

Published: 13 September 2012

doi:10.1186/1742-4690-9-S2-P362

Cite this article as: Han et al.: Eliciting broadly neutralizing antibodies against HIV-1 that target gp41 MPER. Retrovirology 2012 9(Suppl 2):P362.

\footnotetext{
Submit your next manuscript to BioMed Central and take full advantage of:

- Convenient online submission

- Thorough peer review

- No space constraints or color figure charges

- Immediate publication on acceptance

- Inclusion in PubMed, CAS, Scopus and Google Scholar

- Research which is freely available for redistribution 